\title{
Late detection of schizophrenia patient VIH-VHC
}

\author{
Karine Bartolo*, Nathalie Labrune, Isabelle Jaquet \\ From 17th International Symposium on HIV and Emerging Infectious Diseases (ISHEID) \\ Marseille, France. 23-25 May 2012
}

\section{Introduction}

After several years, some patients on TSO, became custumers of BZD (40 tablets per day).

During the maintenance with these patients, we can notice that this consummations are rythmed by periods where there is a new outbreak of productives symptoms.

Auditory and visual hallucinations with influence syndrom, persecution syndrom, tense boarder, social isolation, peculiarity contact, mutilations to-himself, disjointed thought.

These symptoms can't be withdrawal symptoms or a decrease of their consummation.

\section{Methode}

\section{Case report}

HDM: He is man, 41 years, co-infected patient (VIH and $\mathrm{VHC}$ ).

ATCD: He's poly-addict with BZD in first line drug.

\section{Symptoms}

- persecution

- tense boarder

- suicidal ideas

- decrease motivation

- decrease memory

- violent acting

\section{Treatment and observance}

He was having TSO from ten years (buprenorphine $16 \mathrm{mg}$ per day) and a large number of hospitalisation before starting the psychiatric disease treatment.

When the diagnosis was established, the treatment LAAA is administrated and the patient progressively gave up the BZD consummation.

The symptoms progressively disappeared. The only time he was hospitalised is because the withdrawal of BZD was too violent.

\footnotetext{
* Correspondence: karine.bartolo@ap-hm.fr
}

Chu Sainte Marguerite, Marseille, France

\section{Diagnosis}

The diagnosis of schizophrenia with deficit disorders was imput to this patient when the symptoms are stand out ,specialy, when he had no drugs: the BZD, taken in exes.

\section{Results}

We observe that the number of hospitalisations has decreased from 2 since the begining of the new long acting atypical antipsychotics (LAAA).

\section{Conclusion}

We must make a difference between psychiatrics symptoms and associated drugs withdrawal clinic signs when we consider poly-drug users who are partially stabilized by a TSO.

Published: 25 May 2012

doi:10.1186/1742-4690-9-S1-P93

Cite this article as: Bartolo et al:: Late detection of schizophrenia patient VIH-VHC. Retrovirology 2012 9(Suppl 1):P93.
Submit your next manuscript to BioMed Central and take full advantage of:

- Convenient online submission

- Thorough peer review

- No space constraints or color figure charges

- Immediate publication on acceptance

- Inclusion in PubMed, CAS, Scopus and Google Scholar

- Research which is freely available for redistribution

Submit your manuscript at www.biomedcentral.com/submit
() Biomed Central 